\title{
Hated without a reason (injustice personalised): A case study
}

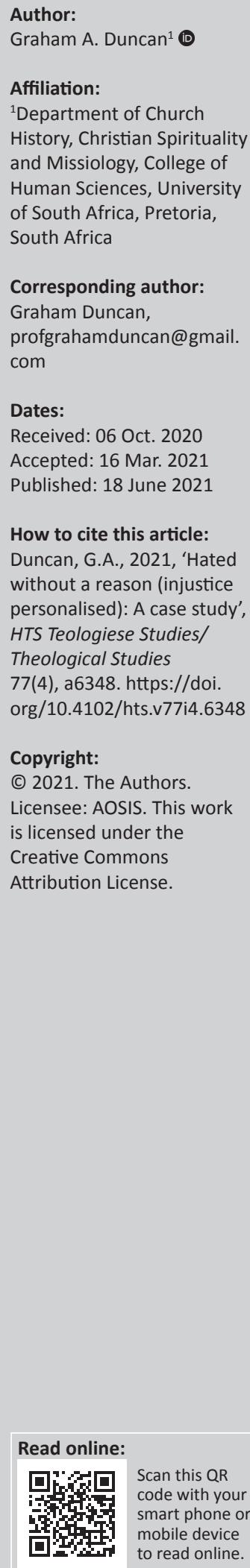

This is the second part of an investigation of the subject of injustice relating to the issue of human sexuality in a mainstream South African Christian denomination. The first paper, entitled 'Hated without a reason I - Contending with issues of human sexuality in a South African ecclesial context: A case study of the Uniting Presbyterian Church in Southern Africa', sought to trace the development of the issue from 1999 to 2016. This article considers the issue from the standpoint of an individual. Within the Uniting Presbyterian Church in Southern Africa (UPCSA), views have polarised along lines determined by views on the authority of scripture and biblical hermeneutics, with little hope for a resolution that will satisfy all the parties concerned despite proposals being made because of a 'failure of love'.

Contribution: This article seeks to extend the discussion on human sexuality in the South African church scene.

Keywords: Committee on Human Sexuality; fundamentalism; homosexuality; justice; Prof. Hansie Wolmarans; Uniting Presbyterian Church in Southern Africa.

\section{Introduction: Justice}

In the first part of this article, I argued that the issue of human sexuality is a matter of justice denied to lesbian, gay, bisexual, transgender and queer or questioning (LGBTIQ) people in South African churches. There I worked with the definition provided by Walter Brueggemann (1986):

[I]n biblical faith, the doing of justice is the primary expectation of God, for God is indeed a 'lover of justice' (Ps 99:4). The way the Bible thinks about justice is: justice is to sort out what belongs to whom, and return it to them. Such an understanding implies that there is a right distribution of goods and access to the sources of life. We control what belongs to others long enough, we come to think of it as rightly ours, and to forget it belonged to someone else. So the work of liberation, redemption, salvation, is the work of giving things back. Justice concerns precisely a right reading of social reality, of social power, and of social good. (p. 5)

The issue of justice in this context centres on the issue of human sexuality.

In terms of the topic of human sexuality, what does justice require of us where gay people have been deprived of genuine love, their dignity, respect (of self and others) and an authentic and meaningful role in the church? Surely, it implies the restoration of justice leading to the assertion of the dignity of all God's creatures, respect from others and within themselves and an authentic role in church and society as we are 'all one person in Christ Jesus' (Gl 3:28), for '[i]t is through faith that you are all sons of God in union with Christ Jesus' (Gl 3:.26). Faith is the prime qualifier for union with Christ. The Uniting Presbyterian Church in Southern Africa (UPCSA) is one denomination that is struggling with the implications of justice in relating to the debate regarding human sexuality.

In the 2016 General Assembly, an overture entitled 'Concerning Christian Marriage' was moved by the Central Cape Presbytery (UPCSA 2016:414). This arose out of the action taken by two ministers of the UPCSA, Revd Martin Young and Prof. Hansie Wolmaran, both from eGoli Presbytery, officiating at the civil union of same-sex couples in 2015. They were not disciplined by the church on the grounds that the UPCSA had not explicitly ruled against this practice at the time. The Presbytery of the Western Cape requested that such a ruling be legislated in direct opposition to eGoli Presbytery, which was seeking permission to allow ministers to participate in the civil unions of same-sex couples according to their own conscience.

The status quo was considered by the movers of the overture to be damaging to doctrine and practice within the UPCSA and was causing 'confusion and division in the Denomination, damage 
our witness, negate the clear teaching of Scripture and undermine the traditional Christian understanding of marriage' (UPCSA 2016:414). This arose out of their belief that 'this matter needs to be resolved clearly and decisively to avoid further damage to the witness, peace and unity of the UPCSA' (UPCSA 2016:414). However, no evidence was presented to demonstrate the level of threat posed by the status quo.

The terms of the overture were:

Assembly to rule as follows (UPCSA 2016):

[A] minister of the UPCSA, whether acting or retired, is not permitted by the denomination to officiate at the civil unions of same sex couples or to perform a blessing service for the civil union of same sex couples. (p. 414)

It was further observed that this overture had been adopted by the following presbyteries, most of whom were unanimous: the Presbyteries of Copperbelt, M'chinga, Munali (Zambia), Zimbabwe, Central Cape, Limpopo, Thekwini, Lekoa, Amathole, Thukela, Transkei, Drakensberg and Highveld.

Then the personal attack began. However, by this time Revd Martin Young had died suddenly. To a degree this changed the nature of the debate in addition to (UPCSA 2016):

$[T]$ he deteriorating relationship between the Presbytery of eGoli and the Presbytery of the Western Cape, as evidenced by a letter from the Moderator of the Presbytery of eGoli,

This led the Presbytery of the Western Cape to rescind the decision taken at the Executive Commission meeting of 8th March, 2016, to adopt and transmit to General Assembly the Overture concerning the doctrinal views of the Rev. Prof. J.L.P. (Hansie) Wolmarans and the Rev. Dr. M. Young. (p. 545)

At the 2016 General Assembly, a notice of motion was presented:

Notice of Motion 7: Rev. Brent Russell [Western Cape Presbytery] gave notice that under the Ministry Committee Report or at another time convenient to the General Assembly he will move the Assembly to note the following facts inter alia:

1. The Presbytery of the Western Cape and the Presbytery of eGoli have been corresponding for well over a year regarding the theological views of Prof. Hansie Wolmarans, Associate Minister of St. Columba's Presbyterian Church, Parkview.

2. According to a statement from commission of the eGoli Presbytery itself, Prof. Wolmarans convinced it with an assurance that he accepts all the subordinate standards of the UPCSA, whereas his own statements make clear that he makes this only on the symbolical level of 'myth' and not the level of what he calls 'logos', or (rational) reality. In his publicly expressed views he has consistently and radically opposed all the fundamental doctrines of the UPCSA.
Professor Wolmarans is a founder member of the Nuwe Hervormde Beweging and an explicit supporter of the 'post-Christian' and 'anti-Christian' positions for which it stands and which it openly propagates.

3. In articles, public lectures and debates placed on the Internet, Prof. Wolmarans explicitly states that Scripture can no longer be regarded as inspired and that 'the master narrative' of Christianity is false in all aspects including the fall of humankind, the incarnation and the doctrine of atonement. He denies the Resurrection of our Lord Jesus Christ and disparages it as a myth concocted on the basis of pagan myths.

4. The documents 'En route to an alternative, secular Christianity' and 'Immanent transcendence in a postfoundational religion: an impossible dream?', which Prof. Wolmarans has placed on the Internet under his name and title as the Associate Minister of St. Columba's Presbyterian Church, Parkview, and allowed to remain there despite the ongoing scandal they have caused, are explicitly atheistic and anti-Christian (see http://www.academia.edu/7403273/En Route to an Alternative Secular Christianity and http://uir.unisa. ac.za/bitstream/handle/10500/4278/Wolmarans.pdf? sequence $=1$ ).

5. Professor Wolmarans' beliefs, teaching and publications contradict the Confession of Faith of the UPCSA ....

6. Despite all the evidence presented to it, the eGoli Presbyterian has to date still failed to act in any way against Prof. Wolmarans or even to distance itself from his publicly expressed views.

7. Professor Wolmarans is currently serving on the Ministry Committee of the General Assembly and is on the nominations committee list to serve again as a member of the Ministry Committee, which selects all the candidates for our ministry and supervises their training. In the light of these facts I shall move further that the General Assembly:

a. In accordance with paragraph 18.4(a) of the Manual of Faith and Order (MOFO) one finds that the allegations contained in points (3) to (7) constitute apparent grounds for discipline and to rule that the Court of General Assembly deal with the issue as a matter of urgency and, if it finds against Prof. Wolmarans, disqualify him from being a minister of our church.

b. Remove Prof. Wolmarans from the Ministry Committee of the General Assembly until this matter has been resolved by the Court of General Assembly.

c. Instruct Prof. Wolmarans to refrain from teaching or preaching in any UPCSA congregation until this matter has been resolved by the Court of General Assembly.

d. Withhold the status of minister emeritus from Prof. Wolmarans subject to the Court of General Assembly resolving the issues (UPCSA 2016:514-515).

There are a number of issues here that are worthy of discussion. Firstly, it is not legally appropriate for one presbytery to insist that another presbytery conforms to its views as is implied in point 1 . Presbyteries can only refer to a 
higher council, that is, the General Assembly. Secondly, a minister's theological views come under the discipline of the presbytery of which he or she is a minister. Thirdly, the UPCSA does not prescribe only one hermeneutic to be applied in the interpretation of scripture (UPCSA 2016):

$[T]$ his church recognises liberty of opinion on all points of doctrine that are not fundamental to the faith. But it retains the right in every case to judge what falls within this description and to guard against any abuse of this liberty that may injure its witness, unity or peace. (p. 414)

Therefore, there is no ostensible issue when Prof. Wolmarans accepts some points of doctrine 'on the symbolical level of "myth" and not the level of what he calls "logos," or (rational) reality'. The UPCSA has never prescribed only one hermeneutic to be applied throughout the denomination. When Revd Prof. Wolmarans became a minister he was examined (as all applicants from other churches are) on Presbyterian doctrine and practice. The mover of the overture took no cognisance of the fact that Prof. Wolmarans was a lecturer in a public university committed to the promotion of research and, therefore, not bound to any confessional standard in pursuit of his academic research. The tenor of the overture suggests that it is not Prof. Wolmarans who is the subject of the proposed discipline but the Presbytery of eGoli for its failure to act against him. No mention is made about the specific 'subordinate standards' of the UPCSA he has contravened. According to the overture, the matter was sent to the wrong council of the denomination to be dealt with.

At the same time, Pinetown Presbyterian Church (Minister Revd Jeremy Smith) within the bounds of the Presbytery of eThekwini petitioned the General Assembly to terminate Prof. Wolmarans' secondment on the ground that (UPCSA 2016):

[C]hapter 16.112 of the Manual clearly states: 'No secondment may be made to secular occupations that have no connection with the work and witness of the Church'.

His teaching, conducted under the auspices of the University of Johannesburg, blatantly contradicts the foundational principles of the Christian faith in a series of categorical statements. It has been argued in defence of Rev. Professor Wolmarans that this heretical teaching is part of his academic work. Such academic work clearly has no connection with the work and witness of the Christian Church; indeed it is our conviction that his teaching has injured the peace and unity of the Church.

We therefore petition the General Assembly to terminate his secondment. (pp. 525-526)

The Moderator correctly ruled that this notice of motion was incompetent (UPCSA 2016:525-526). It is a matter of debate whether or not Prof. Wolmarans' work had 'no connection with the work and witness of the church' since others have been seconded in related circumstances. Again, no evidence was presented that Prof. Wolmarans' teaching was in any way heretical other than in the view of the petitioner.

Mr Russell's overture was converted to a complaint and the General Assembly ruled that Revd Prof. Hansie Wolmarans' status as Minister Emeritus should be withheld pending the decision of the Court of Assembly. The vote was put and the motion was carried. Fifteen commissioners registered their dissent with various reasons given amongst which was that no charges had been laid against Prof. Wolmarans, yet he was judged guilty (UPCSA 2016:529). The Assembly received the complaint, ruling that it appeared that there might be grounds for complaint or a charge of misconduct, and therefore referred the matter to the Court of Assembly and appointed two representatives to present the complaint. By this decision of Assembly, therefore, the option in paragraph 18.60 of the MOFO fell away as unnecessary. The Court of Assembly met to consider the complaint (and other matters) on 01 September 2016.

This complaint was the subject of a report submitted to the Executive Commission of 2017. The purpose of the report was to provide an account of the meetings conducted with Rev. Prof. Hansie Wolmarans as an informal procedure following the issuance of a formal charge sheet of alleged misconduct emanating from a complaint tabled at the 12th General Assembly of the UPCSA and to make recommendations to the Executive Commission of the UPCSA.

The terms of reference of the committee were contained in paragraphs 18.60-18.68 of the Manual of Faith and Order of the UPCSA (the Manual, UPCSA 2007). It reads, in part, as follows:

INFORMAL PROCEDURE 18.60. When an act of misconduct is alleged the Council may, if it wishes, appoint a committee to investigate and report on the circumstances. 18.63 Before the formal judicial procedure begins an alleged offender is offered the opportunity to admit guilt (i.e. to confess to the whole or part of what is alleged) and to show that he or she has repented.

18.67 If the Court of the General Assembly is to act as a Court of first instance, which is rare but is permissible, the rules are the same as for a Presbytery and its Court above.

18.68 If an alleged offender confesses guilt and repents, and the commission from whichever Court it has come decides that no further action need be taken, the hearing is at an end.

Having given due notice to Revd Prof. Wolmarans, the committee conducted the informal meeting with him at Tiyo Soga House on 09 December 2016. Upon reflection following the meeting held in December 2016, the commission, in consultation with the representatives of General Assembly as well as the clerk and the convenor of the Court of Assembly, concluded that the procedure followed during the meeting was flawed because it did not interrogate a formal charge sheet. It was decided that the informal procedure should include a meeting with the accused member where the formal charge sheet may be discussed. The Representatives of General Assembly having drafted a formal charge sheet delivered the formal charges to the accused member. It was agreed that a meeting be held on 26 April 2017 (UPCSA 2017:282). 
Throughout the proceedings, theological hermeneutics dominated the debate. Whilst Wolmarans' detractors insisted on their fundamentalistic interpretation, at least Wolmarans, who disagreed with them, did not attack their position as can be seen in:

CHARGE 1 Teaching which is contrary to the Holy Scriptures and the doctrine of this Church in that you did the following: Asserted that 'A theistic God does not exist' which contradicts sections $3,4,5$ and 13 of the Confession of Faith of the UPCSA. DEFENDANT'S REPLY: We must always keep in mind the Confession of Faith of the UPCSA which states, 'God is always transcendent, infinite, mysterious, beyond human comprehension...' (Article 2). We are only able to imagine God in different ways (UPCSA 2017:283).

Wolmarans challenged the veracity of depending on scientific, philosophical and moral arguments in this regard. His response was detailed and drew on:

Chapter 20, Article 2 of the Westminster Confession, room is available for Liberty of Conscience as a principle. Article 3 of the same confession also deals with the applicability of orthopraxy as opposed to orthodoxy.

f. The Rev. Professor Wolmarans indicated that his theological approach is Protestant liberal and thus understands the Bible from such an approach.

There followed a litany of charges relating to Wolmarans' alleged 'heresy' (UPCSA 2017):

[T] eaching which is contrary to the Holy Scriptures and the doctrine of this Church .... (p. 283), relating to the resurrection, virgin birth, atonement, divine inspiration, the Bible is largely a work of fiction, the Bible as a dubious source of moral behaviour, and opinions contradicting the UPCSA Confession of Faith and the Apostles and Nicene Creeds. On consideration of all of the charges, the committee found the following:

CHARGE 1 ... The allegation as formulated is factually incorrect as to the actual wording of the paper in question. Committee found it puzzling that this mistake, which also occurred in the original document containing the allegations against the member, was transferred to the charge sheet unchecked and uncorrected. It is simply inaccurate and has been proven so.

b. It must be noted that Protestant Liberal Theology is a valid theological perspective within Systematic Theology and is used within mainstream theological debate to help understand Holy Scripture and Doctrine.

c. There is no charge discernible in this allegation - there is no clear rule or church law that has been contravened, nor does it contradict the Confession of Faith of the UPCSA(UPCSA 2017:283).

CHARGE 2 ... Inadequate understanding of the Greek terminology of mythos and logos (UPCSA 2017:285).

CHARGE 3 ... The concept of the virgin birth is both a matter of personal faith and a deeply emotive issue (UPCSA 2017:286).

CHARGE $4 \ldots$ The misquote in the complaint changes the essence of Wolmarans' argument. What is contained in the complaint is simply not what Wolmarans has written (UPCSA 2017:286).

CHARGE 4 ... This charge is not only based upon a misinterpretation of Wolmarans' point of view but also upon a misrepresentation of what he wrote (UPCSA 2017:288).
CHARGE 5 ... The accusation is inaccurate in its content insofar as it ignores the context and meaning of Wolmarans' writing (UPCSA 2017:290).

CHARGE 6 ... Committee finds it difficult to understand how a call for a return to more traditional Biblical philosophy may be regarded as grounds for a charge of misconduct (UPCSA 2017:290).

CHARGE 7 ... Wolmarans does not attack the Bible as a resource for holy behaviour, but questions the issue of moral behaviour based on the Word of God. This is an existing debate amongst believers, and is therefore not an argument unique to Wolmarans.

b. Committee further observed that some practices apparently promoted, tolerated, or by implication condoned in the Bible are no longer regarded as acceptable in modern day social and cultural practice. This includes, amongst others, slavery, male domination over females, killing of other human beings, etc. (UPCSA 2017:292).

CHARGE 8 ... Committee finds no proof or substance in this charge (UPCSA 2017:292).

Throughout, the 'committee/commission's' meeting with Prof. Wolmarans, put each complaint to him, listened to his defence and compiled a report that exonerated him on every charge. All in all, with the dismissal of these charges in their entirety, there remains an underlying impression that these charges were malicious. This is a serious issue in the UPCSA. The MOFO (2007) states:

[A] complainant, if a member of this Church, must be warned by the Council that the bringing of a charge lightly or maliciously is itself an offence and liable to discipline. (p. 18.59)

The report had an Appendix D that contained the critique of the case against Prof. Wolmarans and the findings of the socalled 'Wolmarans Commission' (UPCSA 2017:325-337). The Court of Assembly decided, contrary to the Assembly's decision and contrary to the Manual at several points:

- that the Assembly had 'failed' 'to appoint a committee to investigate whether there was a legitimate charge to answer' (MOFO 2007:8.60)

- that such a committee did need to be appointed to investigate the charges

- that it would therefore ask the Moderator, Clerk and Treasurer of the General Assembly to 'appoint a Commission, in terms of paragraph 18.60, to investigate the accusations against the Rev. Prof J.L.P. Wolmarans to determine whether there is a charge to be answered and, if there is, to administer the "Informal Procedure" outlined in paragraphs $18.63-68^{\prime}$.

- that 'the report' of the committee 'must be received by the Court of Assembly'

- that the Moderator should 'report on this action to the Executive Commission in 2017' (All the quoted wording is from a letter of the convener of the Court to Brent Russell dated 17 March 2017) (UPCSA 2017:325-326).

The Court met again on 11 May 2017 together with the Assembly's Representatives inter alia to discuss the report of the 'commission'. At this meeting, however:

- Brent Russell, as one of the representatives, made the point, not for the first time, that a committee appointed in 
terms of paragraph 18.60 should report to the Assembly, not to the Court

- Jeremy Smith, as the other representative, objected that it would be unfair to go ahead with discussing the report in the absence of Prof. Wolmarans, because he could not defend himself. The Court thereupon:

- found that after all it was correct that a committee appointed in terms of paragraph 18.60 should be called a committee, not a commission

- decided to refer the whole matter, with the report of the committee/'commission', to the Executive Commission (UPCSA 2017:326).

A number of issues arose. Firstly, by deciding in terms of the Manual's provisions that 'it appears that there may be grounds for [a charge of] misconduct' and referring the complaint to the Court, the Assembly obviously let the option for an investigating committee in paragraph 18.60 fall away as unnecessary in this instance. Secondly, the Court had no authority to overrule this decision of the General Assembly and in doing so acted ultra vires. Thirdly, by approaching the Moderator, Clerk and Treasurer of the General Assembly to appoint such a committee and by the Moderator's acceding to the request, when the Manual makes no provision for this, both the Court and the Moderator acted ultra vires in this regard. Fourthly, by ruling that the investigating committee should report to the Court and the Moderator's acceding to this, both the Court and the Moderator acted ultra vires in this regard as well. Fifthly, the Manual provides that the Court should appoint and send 'a commission of three or more people', of whom at least two must be ministers and at least one an Elder, to carry out the Informal Procedure outlined in paragraphs 18.63-68; it does not provide for any committee appointed in terms of paragraph 18.60 or any committee or commission appointed by the moderator to do this. This commission has the task of approaching the alleged offender to offer him or her 'the opportunity to admit guilt (i.e., to confess to the whole or part of what is alleged) and to show that he/she has repented' (para. 18.63). This was not done. The Court and the Moderator acted contrary to the provisions of the Manual and ultra vires. Sixthly, the Manual very clearly distinguishes between the committee envisaged in paragraph 18.60 and the commission envisaged in 18.63ff. The Moderator and the committee/'commission' itself all failed to abide by the provisions of the Manual. By confusing their separate and different mandates and tasks and by confusing these bodies, merging their mandates and tasks and mandating the committee to carry out the task of the commission the Court, they also failed to take paragraph 18.60 seriously in that it specifically calls the body for which it provides a committee because it is not meant to have the powers for 'recommendation, action or decision' that a commission has, or may have (see para. 13.4).

\section{The report states bluntly (UPCSA 2017):}

$[O]$ ne suspects that the Court itself decided in the end to refer the whole matter to the Executive Commission because it began to realize that it had badly messed-up the procedure and wanted the Executive Commission to sort it out somehow. One can only hope that it did not think that the findings of the so-called 'commission' disposed of the matter and wanted the Executive Commission to bury it officially! What is true is that the mess-up has been so critical that it has potentially damaged the whole process. (p. 326)

It also impugned the integrity of all concerned and further perpetrated the injustice against Prof. Wolmarans. It was the opinion of the committee that (UPCSA 2017):

$[T]$ he Executive Commission should rule that the proceedings followed so far, including the appointment of the committee/'commission' and the production of its report, were gravely irregular in terms of the rules of the Church, declare them null and void, refuse to receive or debate the report and refer the whole matter back to the Court to proceed with as the Assembly indicated and in accordance with the rules of the Manual process. (p. 327)

This led the committee to a conclusion that went beyond the case in point (UPCSA 2017):

$[O] n$ all the above grounds, therefore, quite apart from the actual contents or 'findings' of the report of the committee/'commission', the Executive Commission should rule that the proceedings followed so far, including the appointment of the committee/'commission' and the production of its report, were gravely irregular in terms of the rules of the Church, declare them null and void, refuse to receive or debate the report and refer the whole matter back to the Court to proceed with as the Assembly indicated and in accordance with the rules of the Manual (of Faith and Order, MOFO). At the same time it is clear that the Court and the Moderator both misinterpreted the pertinent paragraphs in the Manual and their powers as set out in the pertaining paragraphs. (p. 327)

On reference to the Manual committee, its convener stated (UPCSA 2017):

$[I] \mathrm{t}$ borders on the bizarre to think that the Court could delegate its functions or that some ad hoc Committee could take it upon itself to make recommendations to the Court as to how it, the Court, should deal with the matter. (p. 327)

In response to this, the Presbytery of eGoli (UPCSA 2016: 545-547) submitted an overture to the 2016 General Assembly. It reminded the Assembly that it had in 2006 committed the UPCSA to continued engagement, study and prayer over this contentious issue because any decision on homosexuality could not be divorced from the whole area of human sexuality (and indeed the entire life and witness of the UPCSA) and there needs to be a basic consistency in the way sexual ethics are applied to all sexual relationships.

The Presbytery of eGoli took up the matter of the issue in Zambia and Zimbabwe, which was being used as an argument to prohibit same-gender unions and further noted that this was irrelevant because neither country had laws, which prohibited same-gender relationships. And if they have such laws, how would that affect the argument when South Africa did have such laws? The argument had to be consistent. If same-gender unions were prohibited in Zambia 
and Zimbabwe because of the law, surely the same argument would apply in South Africa regardless, even if that law permitted same-gender unions (UPCSA 2016):

[T] he Presbytery of eGoli overtures the General Assembly of the UPCSA to take into consideration that the issue of same-gender relationships and civil unions are issues that have the potential to divide the Church, given that this matter is much more complex than the simple matter of whether or not it accepts same sex unions. It devolves into theological understanding, the Constitution of the country in which we reside. It would be irresponsible to expect the General Assembly of the UPCSA to make a ruling that will alienate one party or another.

All these issues should be addressed again in a manner that assist the making of the decisions that are long overdue, and which create the space for all parties on both sides of the continuum in this debate, to freely practise their convictions while maintaining mutual respect for one another, within the Church. (p. 547)

Friday 11 August 2017 at 10:00 was set as the date for the Informal Procedure. Professor Wolmarans indicated that in his opinion in the entire process he had complied with everything the UPCSA had required of him with regard to these issues to date; he further indicated that the UPCSA's failure to follow correct procedures was not his fault. He felt that he had already been severely prejudiced by the situation having been a target of malice and defamation of character (UPCSA 2018:244). Here was a blatant example of the injustice perpetrated against him. He refused to plead and a plea of not guilty was entered on his behalf.

The convener of the commission, Revd William Pool, in a letter to the members of the Court of Assembly wrote that (UPCSA 2018):

$[U]$ nfortunately, is an issue that is causing extreme hurt to many people in our denomination, and so is having to be dealt with at many different levels and in many different ways ... I feel that this issue (the Wolmarans case) is proving to be extremely hurtful and destructive to our denomination. I have been the 'joyous' recipient of some colourful emails from both sides of the argument telling me what they think of me. (p. 246)

The purpose of the letter was to request that the matter be referred to the Court of Assembly. It could be argued that the actions of the Court in focussing on an irregularity: 'You turned down the work of the Commission on a technical point of law that had no bearing on the work of the Commission' (UPCSA 2018:246). This had a negative effect on Prof. Wolmarans because he had to go another year with the threat of disciplinary action hanging over his head. The convener of the commission Pool raised matters concerning natural justice (UPCSA 2018):

$[I]$ ssues of natural justice and due process are best summed up when dealing with hearings, tribunals and court cases and at its very core is the notion that these hearings, tribunals etc. must be fair. Considerations of 'fairness' include notification of the hearing; the opportunity to be heard (audi alteram partem); the conduct of the hearing and the right to representation, all of which were met by the Commission. We are arguing that by the
Court deferring this process the Court is in fact deferring the process of natural justice. We are arguing that the reasons given by the Court for turning down the work of the Commission bear examining, and after being examined, are found to be wanting. (p. 247)

The General Assembly ruled on a number of matters relating to this matter in terms of the informal procedure. It confirmed the participation of Revd Dr P.D. Langerman in the work and decision-making of the commission and noticed that the process was now completed. It dismissed the commission with thanks. Furthermore, it required its representatives appointed in 2016 in terms of clause 18.61 of the Manual in the matter of Prof. J.L.P. Wolmarans to consult with UPCSA theologians in UPCSA institutions and elsewhere to prepare thoroughly the evidence to be presented to the Court, and the witnesses to be called, to deal with the issues of faith and doctrine to be adjudicated by the Court. It then made provision for the necessary costs involved to be met.

Based on a notice of motion from the Presbytery of Tekwini, the Assembly observed the unanimous ruling of the Presbytery of Thekwini on the teaching of Revd Prof. J.L.P. Wolmarans and our call to all our members to doctrinal integrity: 'The Presbytery of Thekwini at its meeting on the 21st November 2017 reaffirms its commitment to, and its adherence to, the basic tenets of the Christian faith as set out in the Preamble/Declaration of Standards (2.1) in Chapter 2, The Faith of the Church, in the Manual of Faith and Order of the UPCSA'. In doing so, this Presbytery rejects all novel and deviant doctrines, ideas, proposals, suggestions and thoughts concerning the Christian faith written by Prof. H. Wolmarans in his published papers such as 'En Route to an alternative, secular, Christianity' (UPCSA 2018:614).

Matters proceeded apace and, in order to avoid an extremely costly legal case, it was agreed to refer the process to mediation. This had its origin in the engagement of Revds Jeremy Smith and Brent Russell with 'various general secretaries and moderators' in an attempt to resolve the matter. It needs to be clear here that resolution in their minds refers solely to Prof. Wolmarans withdrawing his theological views. For them the righteousness of their cause prevented any serious discussion or negotiation.

However, on 10 July 2019 the two ministers met in Johannesburg with Prof. Wolmarans and his legal team to see if a mediated outcome could be reached. By agreement between the parties Bishop Emeritus Peter Lee was appointed as independent mediator. Surprisingly, a mediated settlement was reached.

A day later, the Moderator of General Assembly issued a statement in which he commented (Langerman, Presbyterian Link, July 2019):

$[A]$ long and sad chapter in the life of our denomination ended yesterday as the matter of the UPCSA vs the Rev Prof JLP 
Wolmarans was resolved through a mediated settlement. While the parties agreed to keep the agreement confidential, they agreed that the following should be publicly released. (p. 6)

\section{UPCSA (2019a, 2019b):}

[Y]ou are informed that the UPCSA and Prof JLP Wolmarans have settled the disciplinary matter that began after 2014 General Assembly. We acknowledge that the procedures as set out in the Manual of Faith and Order in relation to discipline were not applied correctly nor consistently by the various courts, committees and commissions of the UPCSA that dealt with this matter. The effect thereof was the prolonging of the matter and was the cause of unnecessary and substantial hurt to Prof Wolmarans and his family. Special apology is made to Mrs Wolmarans in this matter for the embarrassment and hurt caused. For this hurt the UPCSA apologizes and undertakes to review the current disciplinary dispensations. Prof JLP Wolmarans and the UPCSA acknowledge that the views expressed in his academic article 'En Route to an alternative secular Christianity' are not per se the views of the UPCSA and are part of an exploratory academic discussion. This agreement constitutes full and final settlement of this matter and any and all claims that the parties (UPCSA, Prof Wolmarans, Rev Smith, Rev Russell) may have against each other arising from this matter and/or the relationship between the UPCSA, Prof Wolmarans, Rev Smith and Rev. Russell. Notwithstanding the aforementioned, Prof Wolmarans retains the right, if any, to pursue a claim for compensation, in the nature of loss of income, against the UPCSA arising from what he contends was an unlawful suspension (10 July 2019). (p. 295)

This confidentiality agreement was strange because firstly, this was not a private dispute but a matter that affected the entire denomination. Furthermore, this left a number of questions unresolved. It was clear that the matter was ongoing, so how would it be possible if some participants were in possession of information denied to others? Was there some internal private agreement, which would favour one side over the other? What was the danger that would emerge from full disclosure? The outcome was open to interpretation (something the fundamentalists were sure to wish to avoid) and to lead to distrust. Secondly, this denied the South African values of transparency and accountability (De Vos 2012):

[I]t is a rather inconvenient fact (inconvenient for some people, at least) that the notion of an open, transparent and accountable government runs like a golden thread throughout our Constitution. (p. 1)

Comparatively speaking, it is understandable why some would wish this also to apply to ecclesiastical matters.

In the matter of UPCSA vs. Prof J.L.P. Wolmarans, SETTLEMENT AGREEMENT, a number of agreements were reached:

Firstly, the UPCSA withdrew unconditionally and with immediate effect the charges against Prof. J.L.P. Wolmarans in the disciplinary matter instituted by the General Assembly. Secondly, it was confirmed that the power to grant
Prof. Wolmarans Emeritus status vests with General Assembly and/or its Executive. This issue was removed and referred back to the Executive Commission of General Assembly to finalise at the Executive Commission in September 2019. The executive was hereby requested to convey to Prof. Wolmarans and the UPCSA its position regarding his status as a matter of urgency and by no later than the end of September 2019. Thirdly, the parties acknowledged that the UPCSA recognises liberty of conscience subject to the Confession of Faith of the UPCSA and undertook to exercise their ministries in the church in that spirit. Fourthly, Prof. Wolmarans and the UPCSA acknowledged that the views expressed in his academic article 'En route to an alternative secular Christianity' were not per se the views of the UPCSA and are part of an ongoing exploratory academic discussion. Fifthly, the UPCSA apologised publicly as noted above.

What is noteworthy is that the merits of this matter, that is, whether the article that Prof. Wolmarans published was in conflict with the foundational faith tenets of the UPCSA, were not dealt with in the settlement. This is largely because there could be no agreement taking into account the theological views of the parties concerned.

This indicates that there had been no movement on either side of the argument, which was theological in nature. Then secular influences took over. Smith commented (UPCSA 2019a):

$[A]$ s representatives we made the decision to settle the matter because of the substantial legal risk to the UPCSA and to us in our personal capacities. The substantial legal risk was created by the failure by the UPCSA to deal with the matter decisively in a procedurally correct manner, consistently and correctly in terms of the Manual of Faith and Order. We were also of the opinion, that Prof Wolmarans had been prejudiced by this. We too had been prejudiced by this. Prof Wolmarans was (and is) represented pro bono by a senior counsel advocate and a top legal firm in Sandton. In fact, the said senior counsel advocate is part of a group of advocates which support the furtherment of constitutional issues that challenge the foundations of our faith and the teachings of the Bible. Prof Wolmarans refused that the mediation talks be opened in prayer. He commenced, in his opening statement, to threaten both myself and Rev Russell with legal action in our personal capacities. In this regard we were advised by our legal counsel that even though a claim against us in our personal capacities would barely succeed, that the best course of action was the mediated settlement, especially given the [financial?] state of the UPCSA, and the negative effect that such litigation would have upon our families, our ministries and the witness of the church. In this sense we believe we have been seriously compromised. (p. 294)

Then Smith introduced other reasons for the settlement. He argued that the eGoli Presbytery failed to address the complaints and charges in this matter properly from the start as it inter alia confused the process, misunderstood the mandate given in the Manual, failed to apply its mind to the evidence provided and never properly interviewed the complaints before making its decision. Secondly, because of 
the ignored instructions, poor communication and poor administration, the Clerk of the Court of General Assembly substantially undermined the correct procedure, thereby strengthening Wolmarans' defence on grounds of improper process and procedure and exposing the UPCSA to the threat of legal action. Thirdly, his most important argument was that the Court of the General Assembly incorrectly advised the then Moderator of General Assembly on how to manage the case. Despite the clear decision of General Assembly in 2016, the Court ruled that a committee should be appointed. This committee was incorrectly appointed as both a committee and a commission and was given a confused mandate. Despite repeated phone calls and e-mails, the then Convenor of the Court, and the Moderator under his direction, ignored the advice and continued in a manner outside of the bounds of the Manual. These errors were corrected by the General Assembly Executive Commission in 2017. However, this resulted in confusion and complications to the case and a delay of more than 1 year. This ultimately undermined the process and procedure outlined in section 18 of the Manual (UPCSA 2019a:294-295).

It is interesting to note how theological principle could so easily be set aside when the cost of dealing with the matter became a significant factor. Firstly, there was the cost to the church and then to the complainants. In truth, a court case would probably have bankrupted both parties, and to what end? Yet, the question remains as follows: what is the price of theological integrity? The denomination had not sought this fight. It emerged from within and from one particular theological view that denied the broad church theological position of the UPCSA. It had its own view of the Reformed inheritance although it has never substantiated this view (Russell \& Smith 2019):

$[T]$ herefore, although the Wolmarans matter is concluded, the struggle to re-establish the doctrinal identity of the UPCSA in relation to its creeds and confessions, critical to its continued existence in life and law, has just begun.

Again there is no definition of the lack of or problem with the 'doctrinal identity' of the UPCSA, other than that it does not conform to the standards of Russell and Smith. The matter of what is critical for the denomination is a matter of discernment and many members do not depend on a definitive position on this matter, which is not of the substance of the faith. It appears from this statement that the protagonists are on a mission to save the UPCSA from itself.

It is interesting to note that Prof. Alan Boesak (2019) raised this very issue in his message to the 20th anniversary celebrations of the UPCSA, held in Port Elizabeth on 27 September 2019:

$[S]$ o the question is not whether we are religious, or Christians: the question is what kind of Christianity are we embracing? I am speaking of the waves of Christian neo-fundamentalism imported from the U.S. washing over Africa and much of the global South with its toxic neo-colonialist package deal of scriptural selectivity, presented as 'biblical inerrancy', violent homophobia, patriarchal power, and anti-justice agenda. Its justification of war and violence in the name of Jesus, its religious exclusivism and Christian chauvinism .... (p. 12)

We should learn to resist the temptation to see the global realities through the eyes of the powerful and privileged, but rather through the eyes of the suffering, the weak and the vulnerable, the dehumanized and the demonized, the outcasts and the excluded. Our theology, and hence our preaching, should be anchored in a theology attuned to the cries of the poor and oppressed because I believe John Calvin was right: the cries of the oppressed are the cries from the very heart of God. Calvin is quite radical in this: 'It is then the same', Calvin says, 'as though God heard Godself when God hears the cries and groaning of those who cannot bear injustice'. God presents Godself as the poor and the oppressed. We must not be afraid to say it. (p. 14)

The key to the process of justice is dynamism. Working towards justice has never been a static movement but has operated in time, place and humanly specific contexts. The process of discerning Christian truth is ongoing and progressive. It emerges in faithful living, which involves decision, repentance and new steps forward and sometimes backward, in faith as was the case in the early Christian community, where under severe threat and trauma, the Christian community suffered, endured and grew in numbers and in faith. Focussed on the coming kingdom, their hope sustained them. This is a process of lifelong learning, of negotiation through the complexities of living as we attempt to remain loyal to Christ (Ballard 2007):

[W]e have to live in the mess that is the world and the church. What is being sought, however, is the ability to be true to the fundamental reality of Christ while seeking to embody that truth in and for our time. The result will never be perfect because the Kingdom is not yet here, but we must each work for kingdom values as we can and where we are. (p. 40)

Perfection, like salvation, is not a given; it is something that has to be worked towards as part of life's struggle, although that work has to demonstrate a high degree of authenticity and integrity in the light of our vision and mission. One of the most common criticisms made against the church is its perceived hypocrisy, for example, talking about unity when we actually foster division. What is credible about a church that is polarised and divided within itself? The focus is Christ, the Word of God incarnate.

\section{Summary}

Historically, this was a PCSA issue brought into UPCSA at the time of the union. Throughout the progress of the entire matter there was no evidence of caring for those most intimately affected and a singular lack of mutual care, which is the prime aim of church discipline: 'to care for and correct rather than punish' (UPCSA, MOFO 2007:18.1), much loved by some in order to promote their own prejudices. Although the term was never overtly expressed, this appears to have been a matter with homophobia at its heart. All negative comments on the 
matter emanate from a fundamentalistic hermeneutic. The fundamentalists were oblivious to any and all arguments, even from scripture that were not consistent with their own views. It did not matter how many reports taking account of all the issues raised were prepared and presented the no compromise status of the fundamentalists remained.

Any mention of the relational aspect contrary to scripture was denigrated. There was no preparedness for engagement, nor was there any mention of justice throughout. Hence, with regard to the Wolmarans matter, the manifest injustice was compounded by the fact that Prof. Wolmarans was never convicted of any wrongdoing.

An ongoing issue relates to the matter of injustice. How could an issue that is not a matter relating to the substance of the faith come to dominate the agenda of the UPCSA over such a long period of time? And then, how did this relate to the Mission and Vision statement of the UPCSA in terms of priority? The vision statement is contradicted by those who do not work towards the formation of a reconciled community:

To be a reconciled community of Christians exercising a prophetic witness to Christ.

The term 'justice' appears in the mission statement:

We will proclaim our Triune God in Southern Africa through:

Visibly proclaiming the Kingdom of God through unity, justice, peace and love.

Then it appears in the mission priorities:

4. Engaging in reconciliation and justice (UPCSA 2019b:2).

This indicates that the achievement of justice is a priority for the UPCSA. Those who wish to impose their views on the denomination must square them with these values.

Why does everyone have to have the same views on morality and ethics forced on them, to the extent that their consciences are offended? And then, why does the church need to take a clear position in this matter? There are various views in the denomination regarding baptism, which is, unlike the matter of human sexuality, an issue relating to the 'substance of the faith'. Such an approach would minimise the tensions caused by absolutising positions and allow 'freedom of conscience' to operate.

\section{Conclusion}

One thing that emerges from this study is the lack of love that impedes any resolution of this contentious matter. In an attempt to 'protect' the faith, the integrity of individuals has been impugned and dreadful injustices have been committed, not least in eschewing due process when differences emerge. For too long, evasion rather than engagement was the modus operandi. Rather than intimate (free open exchange on an emotional and intellectual level) and intense discussion there was a war of attrition in between the councils of the UPCSA. This became a winnertake-all rather than a win-win situation where the gospel and the integrity of the UPCSA were seriously compromised and the cause of justice was denied.

\section{Acknowledgements Competing interests}

The author declares that they have no financial or personal relationships that may have inappropriately influenced them in writing this article.

\section{Author's contributions}

G.A.D. is the sole author of this article.

\section{Ethical considerations}

This article followed all ethical standards for research without direct contact with human or animal subjects.

\section{Funding information}

This research received no specific grant from any funding agency in the public, commercial or not-for-profit sectors.

\section{Data availability}

Data sharing is not applicable to this article as no new data were created or analysed in this study.

\section{Disclaimer}

The views and opinions expressed in this article are those of the author and do not necessarily reflect the official policy or position of any affiliated agency of the author.

\section{References}

Ballard, P., 2007, 'The scriptures in church and pastoral practice', Transformation 24(1), 34-42.

Boesak, A.A., 2019, 'Remaining faithful in the wilderness: Prophetic calling, prophetic presence, and the highway of the LORD', Paper delivered at the Uniting Presbyterian Church 20th Celebration of Unity, Port Elizabeth, September 27.

Brueggemann, W., 1986, 'Micah 6:8: What does the LORD require of you? But to do justice, and to love kindness, and to walk humbly with your God?', in W. Brueggemann, S. Parks \& T.H. Groom (eds.), To act justly, love tenderly, walk Brueggemann, S. Parks \& T.H. Groom (eds.), To act justly, love tenderly
humbly: An agenda for ministers, pp. 5-28, Paulist Press, New York, NY.

De Vos, P., 2012, On accountability, transparency and the 'bribing' of journalists constitutionally speaking 12 February, viewed 03 February 2010, from https:// constitutionallyspeaking.co.za/on-accountability-transparency-and-the-bribingconstitutionallysp
of-journalists/.

Langerman, P., 2019, 'From the desk of the Moderator of General Assembly the Rev. Peter Langerman', Presbyterian link, July, p. 6.

Russell, B. \& Smith, J., 2019, Statement on the matter between the UPCSA and Prof. Wolmarans, UPCSA, Johannesburg.

Uniting Presbyterian Church in Southern Africa (UPCSA), 2007, Manual of faith and order of the UPCSA, UPCSA, Johannesburg.

Uniting Presbyterian Church in Southern Africa (UPCSA), 2016, Papers and proceedings, UPCSA, Johannesburg.

Uniting Presbyterian Church in Southern Africa (UPCSA), 2017, Papers and proceedings, UPCSA, Johannesburg.

Uniting Presbyterian Church in Southern Africa (UPCSA), 2018, Papers and proceedings, UPCSA, Johannesburg.

Uniting Presbyterian Church in Southern Africa (UPCSA), 2019a, Papers and proceedings, UPCSA, Johannesburg.

Uniting Presbyterian Church in Southern Africa (UPCSA), 2019b, Ministers' directory, UPCSA, Johannesburg. 